\title{
THE INSTITUTIONES MINORIS DIALECTICAE OF DOMINGO BAÑEZ. AN INTERPRETATION OF ARISTOTELIC LOGIC
}

\author{
Las Institutiones minoris Dialecticae de Domingo Báñez. \\ Una interpretación de la lógica aristotélica \\ Emanuele Lacca \\ Faculty of Theology - University of South Bohemia
}

\section{RESUMEN}

El estudio de la recepción de la silogística aristotélica dentro del siglo xvI y, en particular, en la filosofía de Domingo Bañez, es un lugar muy importante para mostrar como la figura de Aristóteles fue retomada dentro del entorno cultural de la Escuela de Salamanca. En este trabajo, después de una breve presentación de la trayectoria histórica que permite la llegada de la silogística aristotélica a Bañez, se muestra como, en su Institutiones minoris dialecticae, ella es enfrentada a la problemática de la Trinidad y es valorada para su posible utilidad dentro del entendimiento del misterio divino.

Palabras clave: Aristóteles, Domingo Bañez, Escuela de Salamanca, nominalismo, silogística aristotélica, misterio trinitario.

\begin{abstract}
Study of the reception of Aristotelian syllogistic in the sixteenth century and, in particular, the philosophy of Domingo Bañez, is a very important for showing how Aristotle's philosophy was taken up within the cultural environment of the School of Salamanca. This article, after a brief presentation of the historical trajectory bringing Aristotelian syllogistic to Bañez, shows how, in his Institutiones minoris dialecticae, he faces the problem of the Trinity, and how this work is valued for its usefulness in the understanding of the divine mystery.
\end{abstract}

Keywords: Aristotle, Domingo Bañez, School of Salamanca, nominalism, Aristotelian syllogistic, Divine mystery.

The Institutiones minoris Dialecticae, ${ }^{1}$ written by Domingo Bañez at the end of $\mathrm{XVI}^{\text {th }}$ century and published in 1599 in Salamanca by Andreas Renaut, represent one of the most significant example of how to conduct logical studies in the Siglo de Oro's University of Salamanca. This historical period includes $\mathrm{XVI}^{\text {th }}$ and $\mathrm{XVII}^{\mathrm{h}}$ centuries, in which Spanish philosophy and logic reached a remarkable refinement of analysis and constituted a guide in several European universities of that time.

1 Bañez, D., Institutiones minoris dialecticae, quae Summulae vocant, Salmanticae, excudebat Andreas Renaut, 1599. 
Bañez work, divided into five books, aims to recall the Aristotles' and Pedro Hispano's thought, reorganizing themselves in an organic way that allows to build an interesting working scheme, useful to study dialectic, logic and theology. ${ }^{2}$ This modus operandi fully fits in the path traced by the first Spanish logicians whom, at the and of the $\mathrm{xv}^{\text {th }}$ century, studied in Paris Aristotelian logic and dialectic and its Medieval interpretations, as Ockham, Buridan, Juan Mair and Hispano ones. ${ }^{3}$ However, in this work Bañez goes beyond a mere adherence to Aristotle and his interpreters and, upon these, wants to work out a system that enables not only logicians, but also theologians, to understanding the structure of Aristotelian dialectic and logic. ${ }^{4}$ First of all, this necessity arises from the lack of preparation that the students of the University of Salamanca of the first half of $\mathrm{XVI}^{\text {th }}$ century had in logic, Greek and Latin. ${ }^{5}$ As a matter of fact, one of the first questions shown by Bañez in his work deals with the need of understand if Aristotelian logic can be applied to theological issues as, for example, the problem of the names of God or the Trinitarian question.

Aim of this paper is to show the application of Aristotelian syllogistic to the theological Trinitarian problem, done by Bañez at the end of his work, to demonstrate if logical argumentation can be used to solve theological concerns. Interpretative key will be the X chapter of the $\mathrm{V}$ book of Institutiones, entitled De arte syllogizandi in terminis divinis. Through the analysis of this chapter will be more clear how Aristotelian logic and dialectic are re-used and redefined to satisfy the new conceptual perspectives introduced by theological reflexions of Renaissance period. Moreover, this chapter enables to think over the human tools used to explain the res and, in a broader sense, the entire world that surrounds a human being.

II

The analysis of Bañez chapter needs a brief preliminary study on the reasons why Institutiones are thought by Bañez as an helpful work to theological studies, beyond the historical contingencies. Generally speaking, among Medieval logicians - and this is clear for example in the Hervaeus Natalis' Tractatus de secundis intentionibus, XIV century work that focuses on theory and logic of knowledge- logical and dialectical themes are completely unbundled by theological ones and these are generally studied in a different and separate way. In his Tractatus, Hervaeus writes that the divine attribute «quae est eius [Dei] substantia sit qualitas secundum rationem, sive secundum nostrum modum intelligendi». ${ }^{6}$ Say something pertaining God's substance, as any of His attribute, does not imply the deduction of elements derived by a knowledge or by an inductive process coming from a matter effectively knowable. This kind of interpretation expresses, on the contrary, a completely arbitrary construction, resulting from an individual resolution that does not follow any good-structured theoretical and logical basis. It follows that God can be expressed, from the conceptual point of view, only through trials of faith.

2 See García Cuadrado, J. Á., Domingo Báñez (1528-1604). Introducción a su obra filosófica y teológica, Serie Filosofía Española, Pamplona, 1999, pp. 72-75.

3 See Muñoz Delgado, V., «La lógica en Salamanca durante la primera mitad del Siglo XVI», Salmanticensis, 14/1 (1967), p. 175.

4 On the excessive pedagogical importance given to the Summulae, see Muñoz Delgado, V., «La enseñanza de la Lógica en Salamanca durante el Siglo XVI», Salmanticensis, I (1954), p. 135.

5 See García Cuadrado, J. Á., Domingo Bañez, o.c., p. 75.

6 Hervaeus Natalis, On Second Intentions. Translation \& Latin Version, ed. John P. Doyle, Marquette University Press, Milwaukee (WI), 2008, p. 400. 
In the philosophical and scientific context of $\mathrm{XVI}^{\text {th }}$ century Europe occurs a change of perspective; indeed, in the University of Paris and in Spanish universities the work of theologians quits this justification by faith. They tried to demonstrate the possibility to elaborate a logical theory that could satisfy also the discussions on God. Among these theologians, scholars of logic and dialectic, were studied authors as Aristotle, Pedro Hispano, Georgium Bruxellensis and Stapulensis (Lefevre d'Etaples), and the desire to understand in which way ancient logic had formulated the theory of argumentation increased that kind of studies, divided onto Thomist, Scotist and Nominalist (or Ockhamist) chairs.

Besides, the increasing diffusion of Protestant theology texts induced theologians to try to understand the structure of dialectic argumentation, by which refute these new theories, also on the strictly logic and argumentative path.

In this way, really strong is the axis Paris-Salamanca; in the Spanish university, especially from 1508 statutes, Nominalist chair is officially introduced in the academic curricula, and many Parisian scholars are brought to Salamanca to train teachers and to teach and develop the theories about the logic of discourse, in particular those of nominales. ${ }^{7}$ At the same time, many Spanish theologians went to Paris, to deepen their knowledge in logic and dialectic; in particular, the most studied authors were just Aristotle an Pedro Hispano. In Paris, theologians used to study respectively the Organon, together with the Isagoge, and the Summulae, especially the section concerning the proprietates terminorum. Focusing on these texts also meant to stop metaphysical drift undertaken by logical studies in Spanish universities during the $\mathrm{Xv}^{\text {th }}$ century, that started the so-called 'decadence of Scholasticism'. The same Bañez affirms this problem in the first pages of his Institutiones, writing that «many of the metaphysical disputes that engage the moderns are not only harmful to Dialectic, but also hinder his knowledge». ${ }^{8}$

The study of Dialectic, if unified with metaphysical disputes, is harmful and produces an imperfect knowledge of this subject, that falls down in his incorrect application in the logic of argumentation. The historical reason of this interference dwells probably in the absence of correspondence between the books of Aristotelian Organon and the chapters of the Summulae of Pedro Hispano. This lack of correspondence perhaps opened to a multitude of interpretations of Aristotle thought, all different between them. ${ }^{9}$ It was necessary to trace limits to such confusion and pick up the thread of Aristotelian studies, through the return to the reading of Aristotle's texts, whose commentaries are intended by Spanish theologians only as ancillary works to the understanding the thought of the Stagirite in Medieval philosophy, and not as bulwarks forming the theoretical models that multiplied academic disputes. ${ }^{10}$

During the $\mathrm{xv}^{\text {th }}$ century, one of the most interesting attempts of return to the analysis of Aristotle's texts in the study of rhetoric and dialectics, connected to theology, is represented by the works of Pedro de Osma (1424-1480). ${ }^{11}$ Member of the Dominican order, student of the

7 See Muñoz Delgado, V., «La lógica en Salamanca», o.c., pp. 175-176.

8 Bañez, D. Institutiones, o.c., 1. I, t. I, c. II, p. 15: «mirum est qua multa methaphycalia quidam ex moderni disputent: quae non solum inutilia sed incipientibus Dialecticam discere nociva sunt».

9 On the effect of the incompatibility between the texts of Aristotle and Pedro Hispano, see. Muñoz Delgado, V., «La enseñanza de la Logica», o.c., pp. 143-145.

10 See ibid., p. 146.

11 On life and work of Pedro de Osma, see Stegmüller, F., «Ein Beitrag zur spanischen UniversitätsKonzils-und Kertzergeschichte», Römische Quartalschrift, 43(1935), pp. 205-266; Pérez Rioja, Pedro Martínez de Osma, CSIC, Soria, 1980; Santiago-Otero, H., Reinhardt K., Pedro Martínez de Osma y el método teológico. Edición de varios escritos inéditos, CSIC, Madrid, 1987; Fuertes Herreros J. L., «Contra el nominalismo. Humanismo y renovación de la filosofía y teología en Pedro Martínez de Osma (1424-1480)», Revista española de Filosofía Medieval, 11 (2004), pp. 243-255. 
Colegio Mayor de San Bartolomé and then professor of theology in the University of Salamanca, he sets out himself as one of the solver of the dispute on the relations between faith, theology and speakability of Divine names, against the nominalist dialectic. In this way, one of the most relevant works is the Dialogus in quo ostenditur fundamenta humanae philosophiae, quibus fulciuntur verbosiste, plerumque in theologia deficere, probably written between 1474 and 1479. In this brief work, an idealistic dialogue between a master and a disciple, situated among the quaestio disputata and the new literary forms of the Renaissance, Osma shows the reasons that led him to reject the theories of the nominalist dialectic, as it generates argumentations that disagree with theological ones, as the Trinitarian problem. The work, from the stylistic point of view, has an introduction, a conclusion and three intermediate sections: theory of the disciple, answer to the question and answers of the master to the disciple questions. In the introduction is clearly pointed out the main goal of the work, because it is asked

si por la fe, o por la filosofía humana, o por ambar a la vez, la inteligencia del viador, que no está especialmente iluminada para esto, podría demonstrar en las personas divinas alguna diferencia mayor que la diferencia según el nombre o la razón o menor que la diferencia esencial. ${ }^{12}$

The main problem is to understand if philosophy has open access to the truths of faith, as the ones related to the Trinity, trying to demonstrate if it is possible to study them according to the name, the reason and the essence of the content of these truths. This is a very important aspect in the economy of Osma's work, because it states clearly what has to be meant when a philosopher tries to build a theological discourse, that is strictly connected to problems as the Trinitarian one. The difficulty of this new philosophical building is immediately stated by the Dominican in this part of the Dialogus, because human reason is not naturally ready to understand theological questions, as Trinity and so on. In fact, the disciple immediately says that, following the logic of faith and the logic of reason,

nuestra fe pone entre las personas divinas al engendrador y al engendrado, esto es, al Padre y al Hijo. De donde resulta que el Padre y el Hijo se distinguen más por el nombre o la razón [...] según la razón humana, es imposible que lo mismo según lo mismo coincida y se diferencie. Ahora bien, el Padre divino coincide con el Hijo en la esencia y se distingue de El en la propriedad. Luego la esencia y la propriedad se distinguen más que según la razón de la inteligencia. ${ }^{13}$

A deeper analysis of the explanations given by the faith and by the reason about the Divine persons in Trinity, shows that faith and reason agree that Divine persons are mutually different, because faith states that exists a logical difference between Father and Son, instead reason defines, recalling the Aristotelians principle of non-contradiction and principle of definition, the essential relations among Father and Son. But, according to the same principles, the difference between essence and property, referred to the same persons, makes problematic the understanding of what effective is Trinity. However, the combination between name, reason and essence of the terms that define Divine terms are strictly connected to the possibility of building a discussion over them. Here, the disciple of the Dialogus chooses the

12 The quotations of Osma's Dialogus are taken from the Spanish translation made by Fuertes Herreros J. L., Panchón Cabañeros, «Diálogo en el que se muestra que los fundamentos de la filosofía humana, en los que se apoyan los verbosistas, generalmente fallan en la teología (ca. 1474-1479). Pedro Martínez deOsma (1424-80)», Revista española de Filosofía Medieval, 12 (2005), págs. 243-251. For this quotation see p. 244.

13 Ibid.pp. 244-245. 
Aristotelian syllogism, because is the only kind of discourse that allows to decide what is appropriate of something:

a partir de las cosas que conviene a una sola cosa y no a otra, pueden formarse varios silogismos con la segunda figura del siguiente modo: ninguna esencia es respecto a otra cosa; toda propriedad es respecto a otra cosa; luego ninguna propriedad es esencia. Y según este modo se forman también varios desarrollos de la siguiente manera: esta esencia no es respecto a otra cosa; esta propriedad es respecto a otra cosa; luego esta propriedad no es esta esencia. De ahí que parece estar probado por demostración que la esencia y la relación no son en absoluto lo mismo según la cosa. ${ }^{14}$

In particular, the syllogism chosen by the disciple is the second figure syllogism, that is the only one that not only explains the relations of convenience between things, but also assigns these relationships to one and only one thing, excluding the rest. Determining previously that Father and Son don't differ by essence, but by property, the disciple saves the principle of non-contradiction showing that, by the syllogism of second figure and in connection to Divine persons, essence and property are two different things, autonomous and independent. In this context, the disciple points out a well-formed dialectical argument, that says something about Trinity and demonstrates that philosophy can think over these kind of arguments, especially through the use of Aristotelian philosophy and, in particular, of his theory of syllogism.

However, the master warns the disciple to trust on these kind of argumentations, because the instruments used by philosophers are not adequate to explain theological concepts, with the result that «todas las cosas dichas antes no son demostraciones, sino unos sofismas, que te engañan a ti y a los demás». ${ }^{15}$ In this respect, the master gives four arguments: ${ }^{16}$

- human reason is wrong in the judgement of Divine persons, as it does not have the adequate instruments to decide on them;

- $\quad$ it is impossible to assign to Divine persons genus and species, because in philosophy what differs in genus and species, differs also essentially. However, since in God nothing differs essentially, the master finalizes that, by philosophy, human reason can't study Divine persons;

- $\quad$ about the problem of origin, philosophers often refers to the Aristotelian De anima, in which the main theory consists to say that always exist a generating and a generated beings, with the consequence that no one will generates by himself. This is evidently contradictory if referred to God that once again transcend human thinking categories;

- according to the rules derived by experience, each essence differs from each other and is not possible to appreciate two similar species. However, in God this possibility is not given, because of the inherent meaning of the Trinity. Once again, human reason cannot contemplate the Divine in all its profundity, that assumes the connotation of «mystery».

By these arguments, the master categorically concludes that «es fácil ver que la filosofía humana falla en gran parte en las personas divinas. De donde está claro que se equivocan no poco los que, en cuestiones de fe, se apoyan mucho en la filosofía y en la razón humana, como hacen los verbosistas [...]. En mi opinión, no es difícil anular estos sofis-

14 Ibid., p. 246

15 Ibid.

16 See Ibid., pp. 246-247. 
mas que te confunden a ti y a los demás». ${ }^{17}$ The polemical targets of the master, who interprets the idea of Osma, are dialectics and rhetoricians, who sketched sophistry and fallacious arguments, trespassing in subjects such as theology and religion, despite not having the proper tools to conduct a proper study. In fact, when discussing theology, it is always better to prefer the arguments of faith, coming directly from the divine reason, to human ones, who come from a reason that, by its very constitution, was formed from a multiplicity of contingent experiences.

Demonstrating theological arguments by the syllogistic, dialectic and rhetoric is, therefore, an incorrect operation. In the contingency of the world, in fact, the only institution that can give instructions about the theology and religion, without falling into mistakes is the Church which, however, proves nothing in a philosophical sense: «mostrar así no es demostrar, sino más bien alegar lo demostrado por la Iglesia, tal como si alguno alegara una conclusión de geometría demostrada por Euclides». ${ }^{18}$

The Dialogus of Osma, in this sense, is very indicative of the spirit of renewal that is concerning theology and philosophy in the $\mathrm{Xv}^{\text {th }}$ century, especially in the Iberian territory. On one side, there is a return to the reading of the texts of Aristotle, especially the parts of his corpus which deals with the syllogistic theory, deemed unsatisfying in theological sciences. On the other side, the renewal of the problem of dealing with topics such as the Trinity, encounters many difficulties from the philosophical point of view. The Dialogus, in any case, does not offer a final solution to the problem, but is only limited to suggest a reinterpretation of philosophy, in particular that of Aristotle, to limit its application to the field of theology.

The first one who tried to solve this problematic circumstances was Domingo de Soto, by the introduction of a sort of 'breaking paradigm', dealing with the distinction between the texts and their commentaries; leaving aside historical events that determined his awareness of the limits of such logical studies, he edited in 1529 his Summulae, in which he demonstrate the necessity of a reformation in the field of Arts, «amputanda, non extirpanda» $\gg^{19}$ sophismata and formulas that belong to decadent Scholasticism, that are unfruitful from the scientific point of view: de Soto hopes for a reformation of cursus studiorum, not its alteration. This reformation was carried out by the same Soto, and the measure of success of this reformation is pointed out by the several reprints of his Summulae that, from 1529 , arrived up to 1582 .

17 Ibid.

18 Ibid., p. 251.

19 de Soto, D., Summulae fratris Dominici Soto Segobiensis ordinis praedicatorum artium magistri, Impresse Burgis, in officina Joannis Juntae, 1529, prologus. The diffusion of the Summulae of de Soto is remarked by Fuertes Herreros, J. L., «Pensamiento y filosofía en la Universidad de Salamanca del siglo XV y su proyección en el XVI», in Rodríguez-San Pedro Bezares, L. E. (ed.), Salamanca y su universidad en el primer Renacimiento: siglo XV, Miscelánea Alfonso IX, Aquilafuente, Ediciones Universidad Salamanca, 2011, pp. 233 y sig. 
Taking as a model the reforming work of de Soto, ${ }^{20}$ Bañez concretes the restoration of Aristotelian studies and introduces, in his Institutiones, the method by which correctly study dialectic and logic, constantly compared to the Hispano's Summulae. Bañez work is not to be intended as a book of logic for logic scholars, but rather for theology scholars, because the study of dialectic and syllogism has to be disciplined, redefined and rehabilitated in the courses of the faculties of theology. Its absence, as Bañez states in the prologue of Institutiones, is the cause by which «many good students leave theological studies, to dedicate their studies to civil and canon law». ${ }^{21}$ The study of logic is essential and becomes the required prerequisite for all who want to study theology. For this reason, the knowledge of ancient logic has not its own sake, but acquires in Bañez the sense of 'real help' to understand theological questions.

So, this instrumental meaning clearly emerges in the $\mathrm{X}$ chapter of the $\mathrm{V}$ book of Institutiones, in which the Dominican shows his reformist intent in Aristotelic studies and their application in theology, especially in the Trinitarian problem. The discussion about mysterium Trinitatis starts with two warnings, one historical and another methodological:

- from the historical point of view, is clear that many theologians - of which Bañez writes later-tried to study the problem of the definition of Trinity with the instruments of dialectic, through a study «ad legitime syllogizandum de Trinitate»; ${ }^{22}$

- $\quad$ from the methodological point of view, Bañez questions himself if the introduction of Aristotelian logic and dialectic makes necessary the study of syllogisms to understand the Trinitarian mystery. ${ }^{23}$

Under those warnings, Bañez indicates as crucial the definition of a theory «ad contraria sophismata circa mysterium Trinitatis dissolvenda», ${ }^{24}$ also because any Christian philosopher that theorizes recte his thought cannot commit the imprudence to refer his study only to theological canonical tetxs, but has to mediate, ad sobrietatem, between philosophical and theological elements. ${ }^{25}$

According to the Dominican, the starting point is represented by proving the different definitions of Trinity by syllogism, to understand if these ones comply with Christian doctrine or differ from it in some way. Bañez purposes the analysis of four syllogism concerning the definition of Trinity: ${ }^{26}$

20 For the success of this reformation work, don't have to be forgotten the figure of Gregorio Arcisio that, after de Soto, contributed to the reform of philosophical studies at the University of Salamanca, enhancing studies on Clithoveus and Stapulensis. The role of the author in the reform movement is shown exhaustively by Muñoz Delgado, V., «La enseñanza de la Lógica», o.c., pp. 156-159. According to Muñoz Delgado, logic scholars see in the partnership theology-logic the debasement of logic as a science, since it loses its autonomy.

21 Bañez, D., Institutiones, o.c., prologus, p. III: «plures bonae indolis magnaeque spei discipuli animum ad Sacram Theologiam progrediendi deponunt, et ad Iuris Civilis vel Canonici studium se convertunt».

22 Ibid., o.c., 1. V, c. X, p. 270.

23 Cfr. ibid.: «quaero igitur utrum sint necessaria ad syllogizandum in terminis divinis incomprehensibilis mysterii sanctissimae Trinitatis, nova et specialia documenta praeter ea quae naturali lumine a Philosopho tradita et a Philosophis acceptata sunt».

24 Ibid.

25 See ibid., l. V, c. X, p. 272.

26 Ibid., pp. 270-271. 


\begin{tabular}{|c|c|c|c|}
\hline I syllogism & II syllogism & III syllogism & IV syllogism \\
\hline $\mathrm{P}$ & $\mathrm{P}$ & $\mathrm{P}$ & $\mathrm{P}$ \\
\hline $\begin{array}{l}\text { Omnis essentia divina } \\
\text { est pater } \\
\text { (All Divine essence is } \\
\text { father) }\end{array}$ & $\begin{array}{l}\text { Pater generat filium } \\
\text { (Father generates the } \\
\text { son) }\end{array}$ & $\begin{array}{l}\text { Deus est generans } \\
\text { (God is generating) }\end{array}$ & $\begin{array}{l}\text { Filius non generat } \\
\text { (The son does not } \\
\text { generate) }\end{array}$ \\
\hline $\begin{array}{l}\text { Filius est essentia } \\
\text { divina } \\
\text { (The son is Divine } \\
\text { essence) }\end{array}$ & $\begin{array}{l}\text { Pater est essentia } \\
\text { divina } \\
\text { (The father is Divine } \\
\text { essence) }\end{array}$ & $\begin{array}{l}\text { Deus est genitus } \\
\text { (God is generated) }\end{array}$ & $\begin{array}{l}\text { Filius est Deus } \\
\text { (The son is God) }\end{array}$ \\
\hline $\mathrm{C}$ & $\mathrm{C}$ & $\mathrm{C}$ & $\mathrm{C}$ \\
\hline $\begin{array}{l}\text { Filius est pater } \\
\text { (The son is the father) }\end{array}$ & 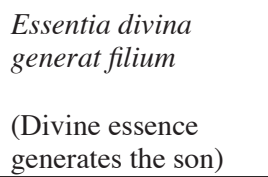 & $\begin{array}{l}\text { Genitus est generans } \\
\text { (The generated is } \\
\text { generating) }\end{array}$ & $\begin{array}{l}\text { Deus non generat } \\
\text { (God does not } \\
\text { generate) }\end{array}$ \\
\hline
\end{tabular}

From the formal point of view, these syllogism are good-generated formulas and comply with the rules of Aristotelian syllogism; however, from the point of view of content show some problems. As a matter of fact, to the consequent terms of the four syllogisms, Bañez observes definitions that are unacceptable to the Christian doctrine and, as consequence, will make impossible any logical study on Trinity. If we also consider that Trinity is matter of faith, and to the sphere of faith pertains al the «not visible», ${ }^{27}$ every logical investigation upon Trinity is really impracticable.

This conclusion does not satisfy Bañez for two reasons:

- $\quad$ should not stand against the rational mechanisms that allow human mind to theorize concrete aspect of the real world, even though the same science deals with ens realis ${ }^{28}$

- $\quad$ theoretically, scientia and fides cannot refer to the same object; however, this impossibility has to stay only in a potential path, because the main work of a theologian must be to dissolve gentilium et haereticorum argumenta, that oppose the mysteries of faith. ${ }^{29}$

For this reasons becomes necessary to find the way to create compatibility among mystery and reasoning, so that Aristotelian syllogism does not remain just an unsolved attempt to explain a mystery as the Trinitarian one. The first element that Bañez remarks is that all syllogisms are of the «expository» $»^{30}$ type, that have as medium a singular term and, for instance,

27 See ibid.: «fides sit credere quod non vides».

28 See ibid.: «nam mysteria fidei catholicae non debent repugnare principiis cognitis lumine naturali [...] intelligentia scientiae agit de ente reali».

29 See ibid.: «scientia et fides non possunt esse de eodem in eodem subiecto. [...] Munus proprium Theologi est dissolvere gentilium et haereticorum argumenta quae obijciuntur adversus fidei mysteria».

30 For a clear definition of «expository syllogirm» see Compendio di tutta la logica secondo l'ordine dell'Organo d'Aristotile, written by Giovan Battista Rossi, Giovanni Guerigi, Venetia, 1618: «il sillogismo espositorio è quello il cui mezzo è termino singolare, ovvero individuo nell'una e nell'altra proposizione e ha la disposizione della terza figura». 
we must pay a certain attention to syllogize about Trinity - composed by three people in the same substance - and syllogize on every member that composes It.

Another aspect of the question that Bañez thinks as essential - and it must be remarked as an evidence of Bañez historical sensibility —is the distinction over the historical context in which Aristotle set up his syllogistic theory. At Stagirite time, it was impossible to formulate argumentations on God and religion in toto similar to those introduced later by Christianity. For example, Aristotle considered the universe as infinite and, at the same time, God as its cause, generating a strong contradiction among God as creature and the universe as His creature. ${ }^{31}$ So, syllogize in terminis divinis should follow the following three rules:

1. God, related to His creatures, is always the cause and what is created simple effect (also the universe);

2. God, as pure act, can create in infinite ways due to His free will;

3. God is the first cause of all things.

Once these three rules, that do not oppose to Christian doctrine, are established, Bañez carries out the redefinition of the syllogistic doctrine within the Christian one.

This redefinition is strictly linked to the reorganization of the academic studies of the theologians of University of Salamanca, as indicated in the 1508 statutes, confirmed in 1529 and 1550 , that ordered to teach primarily the Trinitarian mystery, than the problems of predestination and grace. These three doctrinarian aspects fully mirror the historical efforts of these theologians to counteract against Protestant theological doctrine, based on a reflexion upon the concepts of Trinity, predestination and grace. The work of a Christian theologian is not the same of a logician and, for this reason, is quite different the goal he has to reach using logical argumentation. Bañez suggests a first conclusion on which we should consider:

to syllogize on Divine terms is not a task of the Christian theologian, nor dissolve paralogisms that, in the new Dialectic, counteract the Trinitarian mystery: to study these things suffices the light of reason. This conclusion derives from the solutions purposed at the beginning of the question.

non opus est Catholico Theologo ad syllogizandum in terminis divinis neque ad dissolvendum paralogismos qui contra mysterium Trinitati fieri possunt nova Dialectica: sed sufficit ea quae naturali lumine inventa est. Haec conclusio non aliter comprobatur, quam solvendo argumenta in principio huius quaestionis proposita. ${ }^{32}$

Christian theologian does not deepen in the resolutions of logical and dialectic controversies that involve the formulation of true syllogism about Trinity; refute paralogism and syllogize through reason on Trinity is a job essentially given to the reason and, as consequent, is completely useless to understand mysterium Trinitatis. Indeed, a theologian has to work with syllogism to show how to refute, after the formulation of true sentences on theology, the opposed sentences, avoiding to going into the truth value of the considered syllogism.

In theology, the syllogistic study is then characterized to be «litmus test» to verify the conformity of «rational» judgements on topics hardly explicable by the reason. So, logic does not «intervene» in theology, but follows the latter to allow it to decide about the truth of its theories. The impossibility to go on in the «logicization» of theology, that makes effectively

31 See Bañez, D., Institutiones, o.c., l. V, c. X, p. 272.

32 Ibid., p. 273. 
inexplicable also the Trinitarian mystery, stays in the inability to distinguish from a logical point of view singular and plural terms by which is expressed the Persons of Trinity. In other words, Father, Son and Holy Spirit, expressing three different people and, at the same time, the same substance, are not reducible to singularity of plurality in a grammar path. So, logical reasoning must be stopped.

The main source that inspired Bañez modus operandi is Domingo de Soto, in particular the V book of his Summulae, dedicated to the logical definition of Divine terms. Studying this work, Bañez considers the threefold division made by de Soto relatively to the following terms: ${ }^{33}$

1. terminus essentialis. In these group there all the terms that express the Trinity essence;

2. terminus personalis. In these group there all the terms that refer to only one Person that compose Trinity, as for example the term «Father» and «quod per se et immediate significat personam»; ${ }^{34}$

3. terminus notionalem. In this group there are all the terms that indicate shared expressions by the three Persons, as for example the term «Trinity» in numero plurali.

By this triple distinction is clear the primarily necessity to indicate the considered terms type, before the construction of a syllogism on Divine terms. For example, the construction of a syllogism containing the term «Pater» is different from the construction containing the term «Deus», because the first one is a «personal» term, while the second one is notionalem, i.e. expresses a notion.

However, as the difference among «Pater» and «Deus» is not understandable in a rational level of interpretation, due to the Trinitarian mystery, all syllogisms built on Divine terms are decidable only from formal and doctrinal points of view - that is according to the Christian canon- but not from truthful aspects. Considering this structural profile, Bañez do not try to «logicize» or «rationalize» theology, but questions about how logic and philosophy can go into theology, respecting that investigative sobriety that the Dominican has well pointed out at the beginning of the chapter (pp. 272-273). At the same time, he wants to demonstrate that own logic and philosophy are the subjects that help theologians to oppose themselves to the criticism from the analysis of the doctrinal canon.

The continuation of the chapter, here unanalyzable in details, will be a depth study of the cases and the topics concerning Divine terms and their use in syllogistic. However, the conclusion will the same: it's possible the construction of a syllogistic reasoning about Trinity only if it satisfy the criteria of logical and formal correctness and not the truthful one, because the latter - from a rational point of view - pertains to Divine mystery, that is the sphere of fides.

Syllogize in terminis divinis means to adequate theology and summulistic topics, derived from Hispano and de Soto, successors of Aristotle and his syllogistic in $\mathrm{XV}^{\text {th }}$ and $\mathrm{XVI}^{\text {th }}$ centuries. Bañez logic aspire to be a «service» of truth, maintaining the mystery. This should be unify the philosophical and theological perspectives to reach a deeper understanding of the truth of the Christianity. So, Bañez writes: «in divinis omnia sunt unum, ubi non obviat relationis oppositio». ${ }^{35}$

33 See ibid., p. 273.

34 Ibid., p. 274.

35 Ibid., p. 276. 
Thus, Bañez theory continues those of the Humanistic critics, because he manages to collect the inherence of the Ancient logic, leaving the faults of the logicism and regaining the authentic connection between logic, metaphysics and theology. ${ }^{36}$

Fecha de recepción: día 4 de julio de 2015

emanuele.lacca@gmail.com

Fecha de aceptación: día 9 de septiembre de 2016

36 García Cuadrado, J. Á., Domingo Bañez,o.c., p. 75: «en este sentido, la propuesta bañeciana se sitúa en una línea renovadora paralela a la iniciada por la crítica humanista; esa renovación vuelve a mirar al pasado, pero liberándolo del lastre logicista. Y, sobre todo, recuperando su conexión con la metafísica y la teología». 